Research Article

\title{
IMPACT OF IMPROVED CHICKPEA CULTIVATION ON PROFITABILITY AND LIVELIHOOD OF FARMERS IN DROUGHT-PRONE AREAS OF BANGLADESH
}

\author{
S.C. Sharna ${ }^{*}$, M. Kamruzzaman and S.T. Siddique \\ Department of Agricultural Economics, Bangabandhu Sheikh Mujibur Rahman \\ Agricultural University, Gazipur 1706
}

\begin{abstract}
The cultivation of improved chickpea varieties has been increasing over time that kicks off the local varieties from the farmer's field. Up-to-date socio-economic information regarding this issue is scanty in Bangladesh. That is why we analyze the profitability of improved chickpea variety and assess the impact of its cultivation on the livelihood of chickpea farmers in the high Barind region of Bangladesh. The values of benefit-cost ratio depict that the improved variety is more profitable in comparison to local chickpea variety; specifically, the benefit-cost ratio (BCR) of improved chickpea production is 1.87 , while it is only 1.66 for local chickpea. To understand the wellbeing of chickpea farmers, the multidimensional livelihood index (MLI) following sustainable livelihood framework of the Department for International Development (DFID) is used, which constitutes the asset pentagon of five capitals namely human, physical, natural, financial and social capital. The MLI of improved and local chickpea growers are 0.51 and 0.39 respectively which belong in the middle livelihood category. Meanwhile, the MLI reflects that the improved variety cultivars are in a better livelihood condition than the local variety growers. Among all the five capitals of the MLI, the difference between these two groups is the largest in the case of social capital followed by financial capital. Since both groups have achieved far less MLI values than 1 , the recommendation is therefore to ensure different types of facilities for the development of people of high Barind tract as well as increasing the production of improved chickpea.
\end{abstract}

Keywords: High Barind region, Chickpea, Multidimensional livelihood index, Profitability

\footnotetext{
*Corresponding author: s.sharna.c@gmail.com
} 


\section{INTRODUCTION}

The agricultural sector is the backbone of Bangladesh's economy employing $40.60 \%$ of the total population and contributes to $13.60 \%$ of Gross Domestic Product (BER, 2019). This sector is dominated by paddy prioritized cropping patterns rather than other high value and nutrient-rich crops. In this situation, variation in cropping patterns and raise crop productivity are needed to ensure food security and ameliorate farmer's livelihood. With the increased production of nutritious and high-value crops like pulses and oilseeds, farmers can assure food security along with combating poverty at the grass root-level (Ahmed et al., 2012).

Among all pulses, chickpea (Cicer arietinum) is importantly recognized for the northwestern high Barind region of Bangladesh because of its capacity to grow well in low moisten and unfertile soil (Saha, 2002). This area includes Rajshahi, Chapai Nawabganj, and Naogaon districts. The hard-pan soil in this area is above from the normal flood-level composed of grey terrace soiland low organic matter $(0.8-1.2 \%)$ (Rashid et al., 2017). This tract comprises approximately 0.8 million ha, is also home to the poorest farmers of Bangladesh (Joshi et. al., 2001). Competent technology with institutional changes, not only shapes the agricultural sectors but also uplifts the standard of living (Barrett and Carter, 2010; Bandiera and Rasul, 2006). In particular, chickpea is attractive in this context for its capability to edifice soil quality, its low input requirements and high market price (Saha, 2002). Farmers can start growing chickpea without almost any monetary input after rice production (ICRISAT, 2017). Nonetheless, the area and quantity of chickpea cultivation have been decreasing over time that leads to a copious amount of import bill. The production of chickpea lessened from 61,485 tons (1997) to 6,237 tons (2017) in the last two decades even though yield soared from 0.73 to $1.05 \mathrm{t} \mathrm{ha}^{-1}$ over the period (DAE, 2019). In order to meet the consumption demand, Bangladesh imported 190322 tons chickpea in 2017 that was $96 \%$ of the total chickpea supply in the market in that year (FAO, 2019). Alternately, worldwide chickpea production in 2014 was 13 million tons, whereas it was only 7 million tons in 1971 (FAO, 2019). Hence, it is urgent to increase chickpea production in the country to fulfil people's demands and uplift the farmer's livelihood. For expanding the production and productivity, research institutions of Bangladesh developed many improved chickpea varieties that produce higher yields and are tolerant in different stress conditions. Since the Bangladesh Agricultural Research Institute (BARI) alone has released twenty-seven pulses varieties whereas there are nine chickpea varieties (BARI, 2019). Among all these varieties, BARI Chola-5 is the most cultivated variety in 2018-19 with 438 ha area, followed by BARI Chola-6 (275 ha) and BARI Chola-4 (31 ha) in Rajshahi district (DAE, 2019).

Although many chickpea varieties were developed in the past, only one study was done by Rashid et.al. (2014) on the modern chickpea varieties cultivation and profitability in the Barind region. They disclosed that the benefit-cost ratios are about 2.1 and 1.9 for improved and traditional chickpea varieties, respectively. However, 
the comparative profitability between any specific modern chickpea variety and local chickpea variety has not been computed yet. Despite only a few works that have been done on chickpea farmer's wellbeing, a plethora amount of studies is found about the livelihood of other crops farmers. Only Verkaart et al. (2017) have ascertained the welfare impacts of improved chickpea adoption in Ethiopia. They assessed that the adoption of improved chickpea increased dramatically from $30 \%$ to almost $80 \%$ of the sample throughout 2006-07 to 2013-14. Income from improved varieties contributed up to $20 \%$ of total household income and alleviated household poverty in Ethiopia. About the Barind region of Bangladesh, Saha (2002) stated that chickpea cultivation surged the total farm income of all categories of farmers except the landless farmer. In absolute value, the contribution of chickpea in whole-farm income is highest $(14.0 \%)$ for small farmers followed by the earnings share of large farmers $(11.4 \%)$, medium farmers $(10.8 \%)$ and marginal farmers $(7.7 \%)$. Whereas, Islam (2018) documented that modern T. Aman rice has a positive effect on farmer's wellbeing in rural Bangladesh that is ensured by the increased household income, wet season rice income, wet season rice yield, and household consumption expenditure. Meanwhile, Kamruzzaman and Takeya (2008) observed that both vegetable and rice producers significantly received more profit by inaugurating modern technology and innovative practices. The capacity in terms of the technical, social, human, natural and financial capital was progressed among the farmers who adopt new agricultural practices than the other farmers.

Notwithstanding, many types of research have analyzed the livelihood of farmers (Islam, 2018; Nazli et al., 2012; Kamruzzaman and Takeya, 2008), there is hardly any work about the wellbeing of chickpea farmers of the drought strike area of Bangladesh. For that reason, it is necessary to assess different chickpea farmer's livelihood as well as the comparative profitability of improved and local chickpea variety. The outputs of this study may layout proper directions to the researchers and policymakers about the considerable factors for livelihood upliftment of the chickpea farmers of the high Barind region. Alongside, the comparative profitability between the improved and traditional chickpea variety will provide an entire scenario of cost and return of chickpea cultivation.

\section{METHODOLOGY}

\section{Data and Survey}

Based on the objectives of the study, a multi-stage sampling technique was employed to gather primary data. In order to reveal the most chickpea growing areas, firstly, district, Upazila, and villages were purposively selected. After that, a field survey was conducted in different villages of Godagariand Tanore Upazila of Rajshahi district located in the high Barind region. This area has a high concentration of 
different improved chickpea variety growers along with local chickpea variety producers. A total of 180 farmers were interviewed, among them, 120 respondents were improved chickpea growers (i.e. adopters) and 60 respondents were local chickpea producing farmers (i.e. non-adopters). For this study, the BARI Chola-5 variety is considered as the improved variety. For confirmation of data reliability, data were collected in two different periods. The time length is from $11^{\text {th }}$ to $18^{\text {th }}$ March (during chickpea cultivation) and $9^{\text {th }}$ to $18^{\text {th }}$ June (after chickpea harvesting) of 2019, consecutively.

\section{Conceptualizing and Quantifying Livelihood}

Different agencies such as the Department for International Development (DFID), Cooperative for Assistance and Relief Everywhere (CARE), United Nations Development Program (UNDP), etc. have developed different livelihood approaches. All the organizations link their ideas to the work of Chambers and Conway (1992). According to them, livelihood comprises the capabilities, assets (including both material and social resources) and activities required for a means of living. In this study, the sustainable livelihood framework of the DFID is used comprising the asset pentagon of five different capitals namely human, physical, natural, financial and social capital (DFID, 2000). The asset is grouped into those five broad types of capital. The first one is human capital which represents the skills, knowledge, ability to labour and good health that together enable people to ascertain different livelihood strategies and obtain their goals (Table 1).

Table 1. Eight indicators of human capital used in multidimensional livelihood index

\begin{tabular}{|c|c|}
\hline Indicator & Description and Measurement \\
\hline Household size & Number of a family member in the household \\
\hline Education of farmer & Passed year(s) of formal schooling by the farmer \\
\hline Education of farmer's spouse & Passed year(s) of formal schooling by farmer's spouse \\
\hline Health status & $\begin{array}{l}\text { Number of chronic illness occurred in the household } \\
\text { during the previous year }\end{array}$ \\
\hline Farming experience & Farmer’s farming experience (years) \\
\hline Training & Number of agricultural training received by farmers \\
\hline Mobile usage ability & $\begin{array}{l}\text { Having mobile money transfer account and can use the } \\
\text { mobile internet }=2 \text {; having mobile money transfer } \\
\text { account or can use the mobile internet }=1 \text {; none of this }=0\end{array}$ \\
\hline Crop diversification index & $\begin{array}{l}\text { Crop diversification index (CDI) } \\
C D I=1-H I ; \text { Here, } H I=\text { Herfindahl index; } H I \text { is } \\
\text { calculated from the primary data }\end{array}$ \\
\hline
\end{tabular}


Table 2. Nine indicators of physical capital used in multidimensional livelihood index

\begin{tabular}{|c|c|}
\hline Indicator & Description and Measurement \\
\hline Housing status & $\begin{array}{l}\text { (Wall: brick, roof: brick, floor: brick) }=5 \text {; (wall: brick, roof: tin, } \\
\text { floor: brick) }=4 \text {; (wall: brick, roof: tin, floor: earth) }=3 \text {; (wall: } \\
\text { tin, roof: tin, floor: earth) }=2 \text {; (wall: earth, roof: tin, floor: } \\
\text { earth) }=1\end{array}$ \\
\hline Basic sanitation & $\begin{array}{l}\text { Household has flash toilet=3; permanent toilet=2; temporary } \\
\text { toilet }=1\end{array}$ \\
\hline Access to paved roads & $\begin{array}{l}\text { Concrete road to the house }=3 \text {; brick road to the house }=2 ; \\
\text { earth road to the house }=1\end{array}$ \\
\hline Shop & Dummy, the household has shop $=1$; otherwise $=0$ \\
\hline Motor vehicle & $\begin{array}{l}\text { Dummy, the household has any motorized vehicle }=1 \text {; } \\
\text { otherwise }=0\end{array}$ \\
\hline Water sources & $\begin{array}{l}\text { Household has water pump }=2 \text {; household has tube well }=1 \text {; } \\
\text { household collect water from other house }=0\end{array}$ \\
\hline Agricultural equipment & $\begin{array}{l}\text { Dummy, a household has tractor/power tiller, sprayer, and } \\
\text { spade like equipment }=3 \text {; household has any two of the above- } \\
\text { mentioned equipment }=2 \text {; household has only one equipment } \\
=1\end{array}$ \\
\hline Refrigerator & Dummy, the household has refrigerator $=1$, otherwise $=0$ \\
\hline Television & Dummy, the household has television $=1$, otherwise $=0$ \\
\hline
\end{tabular}

Secondly, physical capital comprises the basic infrastructure and goods incorporating buildings, sanitation facilities, agricultural equipment, etc. which created by economic production processes (Table 2). Whereas, natural capital is the stock of natural resources available for utilization (Table 3). This encompasses both intangible public goods (e.g. the atmosphere and biodiversity) and visible assets that are used directly for production purposes (e.g. trees, land, etc.).

Table 3. Four indicators of natural capital used in multidimensional livelihood index

\begin{tabular}{ll}
\hline Indicator & Description and Measurement \\
\hline Land & Farm size in acres \\
Organic fertilizer & Dummy, household uses organic fertilizer $=1$, otherwise $=0$ \\
Trees & Number of the tree(s) within the house \\
Irrigation water & $\begin{array}{l}\text { Distance to the nearest irrigation sourced from farmland in } \\
\text { meter }\end{array}$ \\
\hline
\end{tabular}


Table 4. Four indicators of financial capital used in multidimensional livelihood index

\begin{tabular}{ll}
\hline Indicator & Description and Measurement \\
\hline Other income sources & $\begin{array}{l}\text { Dummy, household gets remittances/pension/transfer payments } \\
=1 ; \text { otherwise }=0\end{array}$ \\
Credit facility & $\begin{array}{l}\text { Dummy, the household has access to credit }=1 \text {; otherwise }=0 \\
\text { Savings account }\end{array}$ \\
Livestock & Nummy, the household has savings account $=1$; otherwise $=0$ \\
\hline
\end{tabular}

Besides, financial capital involves the financial resource; simply, the stocks of liquid resources to which the household has access (e.g. savings, credit). There are two main sources of financial capital; a) available stocks such as savings, cash, credit, bank deposits, etc.) regular inflows of money like pensions or other transfers from the state, and remittances from outside home (Table 4). The last capital refers to social capital, which embraces networks and connectedness that enrich people's trust and ability to work together and expand their access to wider institutions (Table 5).

Table 5. Description of 4 indicators of social capital used in multidimensional livelihood index

\begin{tabular}{ll}
\hline Indicator & Description and Measurement \\
\hline $\begin{array}{l}\text { Association with GO } \\
\text { and/or NGO }\end{array}$ & $\begin{array}{l}\text { Dummy, the respondent is a part of GO/NGO/any development } \\
\text { program=1; otherwise=0 } \\
\text { Network } \\
\begin{array}{l}\text { Organization } \\
\text { membership }\end{array}\end{array}$ \\
$\begin{array}{l}\text { Women decision-making of agricultural information source(s) } \\
\text { ability }\end{array}$ & $\begin{array}{l}\text { Dummy, having any organization membership=1; otherwise=0 } \\
\text { decisions }=1 ; \text { otherwise=0 }\end{array}$ \\
\hline
\end{tabular}

\section{The Multidimensional Livelihood Index}

For providing quantitative evidence-based index, the Multidimensional Livelihood Index (MLI) is developed in this research. In order to produce indicators with an identical range of 0-1 the Min-Max normalization method is used, which uses the following calculation:

$$
\begin{aligned}
\text { Index }_{i j} & =\frac{x_{i j}-x_{\min }}{x_{\max }-x_{\min }} \\
\text { Index }_{i j} & =\frac{x_{\max }-x_{i j}}{x_{\max }-x_{\min }}
\end{aligned}
$$


Here, Index $x_{i j}$ represents the value of indexed indicator $i$ of major component $j ; x_{i j}$ is the value of the indicator ' $i$ ' of major component or capital $j ; x_{\min }$ is the local minimum value of the indicator, and $x_{\max }$ is the local maximum value of the indicator in the survey area. Equation (1) is employed for the calculation, where the indicators are positively related to livelihood. On the opposite side, equation (2) is used for the indicators that have a negative relationship with the wellbeing of farmers. Thus, the usage of equation (2) is bound for the indicators of health status (measured through occurred chronic illness) and irrigation water (valuated by distance to irrigation sources) because these measurements are negatively related to the development of livelihood. In contrast, equation (1) is used for the rest of the indicators of the multi-dimensional livelihood index. Once indicators are standardized, they are combined using equal weighting to calculate the value of major component or capital by Equation (3):

$M_{j}=\frac{\sum_{i=1}^{n} \text { Index }_{i}}{n}$

here, $M_{j}$ is the value of capital ' $j$ ' and ' $\mathrm{n}$ ' is the number of sub-components or indicators in major component $M_{j}$.

The composite score of the livelihood index is enumerated for a respondent by summing the score of all capitals. Equal weighting is used to combat the complexity and subjective nature of livelihood indices. The equation used for the estimation of MLI is:

$M L I=\frac{\sum_{j=1}^{5} M_{j}}{5}$

\section{Profitability of Chickpea Production}

RESULTS AND DISCUSSION

The comparisons of costs and returns of modern chickpea variety and local chickpea variety cultivation are illustrated in Table 6 . Costs of all items are higher for the traditional chickpea variety than the improved variety only except the cost of hired labour. The land-use cost is the same for all farmers as all farmers belong in the same region. The land preparation cost is a little greater for the traditional variety as more fragmented lands were used for growing local variety which increases the per-acre land preparation cost. Despite, the seed cost is more for improved variety (Tk 116/kg) than traditional variety (Tk $75-90 / \mathrm{kg}$ ), the per-acre seed cost is higher for local variety in the surveyed area. The reason behind this is the compensation of seed from the governmental institutions for instances, Department of Agricultural Extension (DAE) and Bangladesh Agricultural Development Corporation (BADC) that reduces the per-acre seed cost of adopters. Because of the resistance characteristics of improved chickpea variety, the adopters do not have to use a lot of fertilizers and pesticides and/or insecticides that results in less fertilizer and pesticide cost for 
adopters. As the improved variety provides a better yield than local variety, the adopters have to spend more on hired labour for harvesting than the expense of nonadopters. However, the adopters expend less on family labour because they use fewer amounts of fertilizer and pesticide per acre that ultimately tends to results in less utilization of family labour.

Table 6. Per acre cost and returns of improved and local chickpea variety cultivation

\begin{tabular}{lcccc}
\hline \multirow{2}{*}{ Particulars } & \multicolumn{2}{c}{ Improved variety } & \multicolumn{2}{c}{ Local variety } \\
\cline { 2 - 5 } & Mean & SD & Mean & SD \\
\hline Land preparation & 1916 & 183 & $1952^{* *}$ & 154 \\
Seeds & 2048 & 967 & 2065 & 177 \\
Fertilizers & 559 & 118 & $657^{* * *}$ & 102 \\
Pesticides & 466 & 117 & $809^{* * *}$ & 109 \\
Hired labor & 6008 & 788 & $5877^{*}$ & 1038 \\
Total variable cost (TVC) & 11098 & 1472 & $11363^{*}$ & 1098 \\
Land use cost & 9000 & 00 & 9000 & 00 \\
Interest on operating capital & 117 & 15 & 120 & 11 \\
Family labor & 1626 & 38 & $1814 * * *$ & 102 \\
Total fixed cost (TFC) & 10744 & 44 & $10935^{* * *}$ & 102 \\
Total cost (TVC+TFC) & 21843 & 1496 & $22299 * *$ & 1109 \\
Gross return (GR) & 40574 & 2743 & $36937 * * *$ & 2662 \\
Gross margin (GR-TVC) & 29476 & 2901 & $25574 * * *$ & 2963 \\
Net return (GR-TC) & 18731 & 2906 & $14638^{* * * *}$ & 2960 \\
Benefit cost ratio (GR/TC) & 1.87 & 0.17 & $1.66 * * *$ & 0.15 \\
\hline
\end{tabular}

Note: *,**, and *** indicate that mean differences between the BARI Chola-5 variety and local chickpea variety production are significant at the $10 \%, 5 \%$, and $1 \%$ confidence levels, respectively.

Meanwhile, improved chickpea variety is not only more productive but also hasa higher price. Therefore, the adopters get about 15\% higher gross margin, almost 1.3 times the net return of non-adopters earn that finally results in an almost $13 \%$ higher benefit-cost ratio for adopters (Table 6). 


\section{The livelihood of Chickpea Growers}

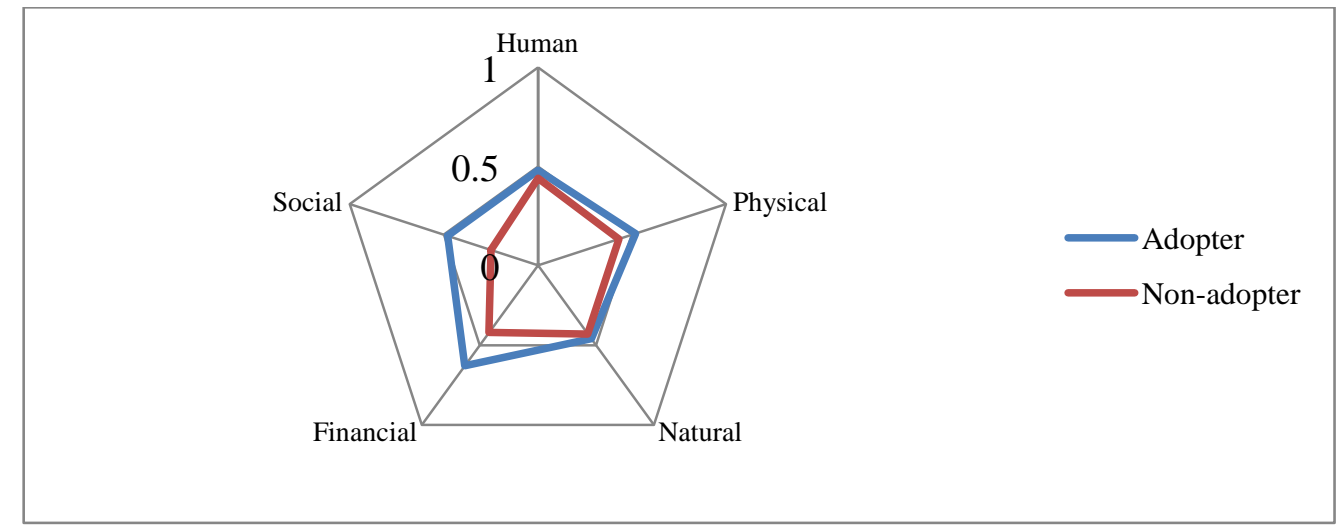

Figure 1. The multi-dimensional livelihood index of adopters and non-adopters

The results of the multidimensional livelihood index reveal that there is a significant difference between the livelihood status of modern chickpea growers and local chickpea cultivators. Table 3 shows that the Multi-dimensional Livelihood Index (MLI) of adopters and non-adopters are 0.51 and 0.39 respectively and the difference between them is significant at a 95\% confidence level. All five capitals of MLI indicate a better position of adopters than the conditions of non-adopters (Fig. 1). Nonetheless, unsatisfactorily, the differences between those two categories are significant only for two capitals (financial and social capital) whereas, the dissimilation is insignificant for the other three capitals namely human, physical and natural capital. However, the differences between these two groups are significant for 21 indicators among 29 of them.

Table 7. Comparison between the livelihood of adopters and non-adopters

\begin{tabular}{clcc}
\hline Capital & \multicolumn{1}{c}{ Indicator } & Adopter & Non-adopter \\
\hline Human & & $0.48(0.21)$ & $0.44(0.22)$ \\
\hline \multirow{6}{*}{} & Household size & $0.38(0.28)$ & $0.56(0.28)^{* * *}$ \\
& Education of farmer & $0.42(0.21)$ & $0.35(0.18)^{* *}$ \\
& Education of farmer's spouse & $0.31(0.23)$ & $0.22(0.18)^{* * *}$ \\
& Health status & $0.92(0.20)$ & $0.86(0.24)^{*}$ \\
& Farming experience & $0.32(0.23)$ & $0.36(0.24)$ \\
& Training & $0.35(0.25)$ & $0.20(0.15)^{* * *}$ \\
& Mobile usage ability & $0.45(0.39)$ & $0.34(0.36)^{*}$ \\
& Crop diversification index & $0.72(0.18)$ & $0.61(0.21)^{* * *}$ \\
\hline Physical & & $0.52(0.25)$ & $0.43(0.22)$ \\
\hline
\end{tabular}




\begin{tabular}{|c|c|c|c|}
\hline Capital & Indicator & Adopter & Non-adopter \\
\hline & Housing status & $0.59(0.23)$ & $0.45(0.23)^{* * *}$ \\
\hline & Basic sanitation & $0.61(0.22)$ & $0.58(0.25)$ \\
\hline & Access to paved roads & $0.75(0.28)$ & $0.60(0.38)^{* * *}$ \\
\hline & Shop & $0.23(0.42)$ & $0.20(40)$ \\
\hline & Motor Vehicle & $0.18(0.33)$ & $0.10(0.26)^{*}$ \\
\hline & Water source & $0.57(0.23)$ & $0.44(0.21)^{* * *}$ \\
\hline & Agricultural equipment & $0.21(0.31)$ & $0.18(0.27)$ \\
\hline & Fridge & $0.78(0.42)$ & $0.70(0.46)$ \\
\hline & Television & $0.78(0.42)$ & $0.65(0.48)^{*}$ \\
\hline \multirow[t]{5}{*}{ Natural } & & $0.46(0.16)$ & $0.43(0.18)$ \\
\hline & Land & $0.36(0.18)$ & $0.21(0.11)^{* * *}$ \\
\hline & Organic fertilizer & $0.68(0.47)$ & $0.62(0.49)$ \\
\hline & Trees & $0.32(0.23)$ & $0.39(0.22)^{*}$ \\
\hline & Irrigation water & $0.49(0.24)$ & $0.51(0.19)$ \\
\hline \multirow[t]{5}{*}{ Financial } & & $0.63(0.17)$ & $0.42(0.11)^{*}$ \\
\hline & Other income sources & $0.40(0.49)$ & $0.35(0.48)$ \\
\hline & Credit facility & $0.68(0.47)$ & $0.33(0.48)^{* * *}$ \\
\hline & Savings account & $0.80(0.40)$ & $0.58(0.50)^{* * *}$ \\
\hline & Livestock & $0.63(0.29)$ & $0.41(0.27)^{* * *}$ \\
\hline \multirow[t]{5}{*}{ Social } & & $0.48(0.15)$ & $0.25(0.14)^{*}$ \\
\hline & Association with GO and/or NGO & $0.31(0.46)$ & $0.18(0.39)^{*}$ \\
\hline & Network & $0.58(0.33)$ & $0.28(0.28)^{* * *}$ \\
\hline & Organization membership & $0.40(0.49)$ & $0.12(0.32)^{* * *}$ \\
\hline & Women decision making ability & $0.62(0.49)$ & $0.43(0.50)^{* *}$ \\
\hline Multidim & ensional Livelihoods Index & $0.51(0.07)$ & $0.39(0.08)^{* *}$ \\
\hline
\end{tabular}

Note: Figures in parentheses are standard deviations. *,**, and *** indicate that mean differences between the adopters and non-adopters are significant at the $10 \%, 5 \%$, and $1 \%$ confidence levels, respectively.

In the first place, the average value of human capital is 0.48 for adopters that are higher than the non-adopters (Table 7). In this study, human capital comprises eight indicators where differences for all of the indicators are significant except farming experience. Among those, the education of farmer and farmer's spouse, health status, training, mobile usage ability, and crop diversification index represent higher value for adopters rather than only household size. The results imply that the adopter and 
their spouses have a better formal education. Some studies also found that hybrid and modern varieties adoption have a positive correlation with the educational status of the farmers (Smale et al., 2018). Furthermore, the adopters have new skills such as the utilization of mobile money transfer account and the internet on mobile. In line with those skills, they receive more training which helped them to adopt new agricultural technology. Besides, the adopter experienced less chronic illness. Again, the adopters produce different types of crops to minimize the risk and uncertainty in agriculture along with gaining more profit. However, the non-adopters have a bigger household size that provides them to grow more labour intensive crops instead of cultivating easy growing crops.

Usually, the physical capital includes infrastructure, machinery, agricultural equipment, electric tools, etc. those are acting as vital for societal development. In this study, there are nine indicators to estimate the value of physical capital. Table 7 depicts that the adopters have a larger value of the physical assets $(0.52)$ than the non-adopters $(0.43)$ which provides improved chickpea variety farmers with a better status in the society. Meanwhile, the differences between these two groups are significant only for the indicators of housing status, the road to the house, water source, and having motor vehicle and television. The livelihood of rural people depends on the spatial factors like road facility as well as other physical factors to a great extent (Donohue and Biggs, 2015).

One of the crucial capitals for the development of rural communities is natural capital, which comprised natural resources like land, pond, sources of irrigation, trees, etc. The estimated value of natural capital shows that both the adopters $(0.46)$ and the non-adopters (0.43) stay almost in the same position (Table 7). Four indicators are set for elucidating natural capital. Among those, the differences between these two groups are significant for the indicators of land and trees. Even though adopters have more than 1.5 times land compared to the non-adopters, local chickpea variety growers have almost $21 \%$ more trees in their homestead area (Table 7).

There are four sub-components of financial capital including outside income sources, credit accessibility, savings account and livestock, which is the most common liquid resource of rural households. The adopters obtain 0.63 for financial capital that is larger than the acquired value of non-adopters (Table 7). In comparison to nonadopters, the adopters have access to about two times credit for agriculture purposes and it turns into profit from the production of more agricultural products. Similarly, the proportion of farmers has a savings account is about $38 \%$ higher for improved chickpea variety producers. Besides, they have 1.5 times more livestock than nonadopters that provide not only daily inflows of money but also a large amount of money at one instance after selling that livestock (Table 7). Meanwhile, some research works indicated that the improved variety adoption and per capita household income have a positive correlation, which ultimately reduces poverty and ensures 
food security (Islam, 2018; Verkaart et al., 2017; Nazli et al., 2012; Mendola, 2007).

The last capital of MLI named as social capital that reports the status of the social relationship of the sample farmers in the surveyed community. The index of social capital is almost double for adopters than non-adopters (Table 7). This capital includes four indicators, for instance, relationship with governmental and nongovernmental organizations, network with different information sources, organization membership and women's position in society. Satisfactorily, the differences between adopters and non-adopters are significant for all of those four indicators. About $31 \%$ of adopters are in association with various types of governmental, non-governmental bodies or government-authorized program. Furthermore, the adopters have a better network with different organizations (e.g. DAE, BADC, BARI, etc.), agricultural input dealers, different Non-Governmental Organizations (NGOs), neighbor, relatives, other farmers, etc. These networks work as information sources that disseminate valuable information about modern and sustainable agricultural technology. Besides, some farmers act as a member of different own managed organizations for community development. These organizations mainly deposit the member's money and provide credit to the farmers with lower interest rate along with some other services. Compared to non-adopter's family, the women in the adopter's family mainly the spouse of farmers can visualize their decision about agriculture. Thus, the women of adopter's family have more influence on agricultural practices.

\section{CONCLUSIONS}

This article is an exertion to divulge the profitability of improved and local chickpea as well as the livelihood scenario of different chickpea farmers in the drought strike region of Bangladesh. The comparison between the livelihood of adopters and nonadopters imparts information about the livelihood of two different groups. Undoubtedly, the improved chickpea variety provide a larger gross margin, net return and ultimately, a bigger benefit-cost ratio than its counterpart. Along with that, the higher MLI of adopters proclaims a better livelihood condition than non-adopter that demonstrates a partial intervention of improved chickpea variety in the high Barind region. As the MLI for adopters and non-adopters are much lower than their full potential, there is a plethora of scope to develop their livelihood scenario. Through promulgating the improved varieties with more productivity and different resistance characteristics, the wellbeing of miserable farmers can be upgraded considerably. In

this circumstance, the more intensive policy is needed to ameliorate the condition of non-adopters through providing other facilities, for instances, better education, proper rural infrastructure, women empowerment activities, income diversifying opportunities along with increasing modern variety cultivation. 


\section{ACKNOWLEDGEMENT}

The authors are grateful to the Ministry of Science and Technology (MoST), Government of the People's Republic of Bangladesh for providing financial support to implement the research work purposively.

\section{REFERENCES}

Ahmed, H., Ahammed, S.U. and Tareque, A.M.M. (2012). Vision Document-2030 for Agricultural Research in Bangladesh. Bangladesh Agricultural Research Council, Farmgate. Dhaka, Bangladesh. Pp. 25.

Bandiera, O. and Rasul, I. (2006). Social networks and technology adoption in northern Mozambique. The Economic Journal, 116: 869-102.

BER. (2019). Bangladesh Economic Review, Department of Finance, Ministry of Finance, Government of the People's Republic of Bangladesh, Dhaka.Pp112.

BARI. (2019). Bangladesh Agricultural Research Institute (BARI). Gazipur, Bangladesh. http://www.bari.gov.bd/site/page/457be85c-3438-45af-a779-5cefcd2405b1. Accessed $12^{\text {th }}$ July 2019.

Barrett, C.B. and Carter, M.R. (2010). The power and pitfalls of experiments in development economics: some non-random reflections. Applied Economic Perspectives and Policy, 32(4):515-548.

Chambers, R. and Conway, G. (1992). Sustainable rural livelihoods: practical concepts for the 21st century. Institute of Development Studies (UK). Pp. 12.

DAE. (2019). Annual Report. Rajshahi Regional Office, Department of Agricultural Extension, Government of the People's Republic of Bangladesh, Rajshahi, Bangladesh.

DFID. (2000). Sustainable livelihoods guidance sheets. Department for International Development, London, UK. Pp. 29.

Donohue, C. and Biggs, E. (2015). Monitoring socio-environmental change for sustainable development: Developing a Multidimensional Livelihoods Index (MLI). Applied Geography, 62: 391-403.

FAO. (2019). Food and Agriculture Data. Food and Agriculture Organization (FAO), Rome, Italy.

ICRISAT. (2017). New variety of chickpea helps Bangladeshi farmers fight climate change. International Crop Research Institute for Semi-Arid Tropics (ICRISAT). https://www.icrisat.org/new-variety-of-chickpea-helps-bangladeshi-farmers-fightclimate-change/. Accessed $6^{\text {th }}$ July 2019.

Islam, A. (2018). Impact of improved rice varieties adoption on farmers' well-being (livelihood) in rural Bangladesh. Bangladesh Journal of Agricultural Economics, 38: 454-534.

Joshi, P.K., Rao, P.P., Gowda, C.L.L., Jones, R.B., Silim, S.N., Saxena, K.B. and Kumar, J. (2001). The world chickpea and pigeon pea economies facts, trends, and outlook. International Crops Research Institute for the Semi-Arid Tropics. Pp. 25. 
Kamruzzaman, M. and Takeya, H. (2008). Capacity building of the vegetable and rice farmers in Bangladesh: JICA intervention. Journal of Sustainable Agriculture, 31(3): 145-161.

Mendola, M. (2007). Agricultural technology adoption and poverty reduction: A propensityscore matching analysis for rural Bangladesh. Food policy, 32(3): 372-393.

Nazli, H., Orden, D., Sarker, R. and Meilke, K.D. (2012). Bt cotton adoption and wellbeing of farmers in Pakistan (No. 1007-2016-79742). Presentation at the triennial Conference of International Association of Agricultural Economists (IAAE), held at Brazil. Pp. 26.

Rashid, A., Hossain, S., Deb, U., Kumara Charyulu, D., Shyam, D.M. and Bantilan, C. (2014).Targeting and introduction of chickpea improved cultivars in Barind region of Bangladesh (Tropical Legumes II Phase 2 Project).Proceedings of $8^{\text {th }}$ International Conference, Viability of Small Farmers in Asia held at Savar, Bangladesh. Pp. 20.

Rashid, M.H.A., Islam, A.B.M.J., Shirazy, B.J. and Shahidullah, S.M. (2017). Cropping systems and land use pattern in Rajshahi region. Bangladesh Rice Journal, 21(2): 237254.

Saha, A.K. (2002). Impact assessment study for the DFID-funded project R7540 Promotion of chickpea following rain fed rice in the Barind area of Bangladesh. Centre for Arid Zone Studies, University of Wales, Bangor, UK. Pp. 24.

Smale, M., Assima, A., Kergna, A., Thériault, V. and Weltzien, E. (2018). Farm family effects of adopting improved and hybrid sorghum seed in the Sudan Savanna of West Africa. Food policy, 74: 162-171.

Verkaart, S., Munyua, B.G., Mausch, K. and Michler, J.D. (2017). Welfare impacts of improved chickpea adoption: a pathway for rural development in Ethiopia? Food policy, 66: 50-61. 